\title{
Influence of soybean storage conditions on crude oil quality
}

\author{
Ernandes R. de Alencar ${ }^{1}$, Lêda R. D. Faroni ${ }^{1}$, Luiz A. Peternelli', Marco T. C. da Silva ${ }^{3}$ \& André R. Costa
}

\begin{abstract}
This study was done to evaluate the quality of crude oil from soybeans stored under different conditions. The grains were harvested at $18 \%$ (w.b.) moisture content (m.c.), and after drying to $11.2,12.8$ and $14.8 \%$ they were stored at 20, 30 or $40^{\circ} \mathrm{C}$. Changes in free fatty acid (FFA) content, peroxide, iodine and photometric color index of the extracted oil were determined at 45-day intervals for 180 -day storage. In general, oil FFA content increased in all the samples, except in grains at $11.2 \%$ m.c. and stored at $20{ }^{\circ} \mathrm{C}$. The peroxide and photometric color index increased significantly, independently of storage conditions; however, the increase was more accentuated in oil extracted of stored grains at high m.c. and temperature. It was concluded that crude oil quality is not affected during 6-month storage of soybeans up to $15.0 \%$ m.c. (w.b.) at $20{ }^{\circ} \mathrm{C}$, and for storage at $30^{\circ} \mathrm{C}$, the grain moisture up to $13 \%$ maintains oil quality within the Brazilian market standards.
\end{abstract}

Key words soybean quality, hydrolytic rancidity, oxidative rancidity

\section{Influência das condições de armazenagem da soja na qualidade do óleo bruto}

\begin{abstract}
RESUMO
Propôs-se, neste trabalho, avaliar a qualidade do óleo bruto extraído dos grãos de soja armazenados em diferentes condições. Grãos de soja foram colhidos com aproximadamente $18,0 \%$ de teor de água (b.u.) e, após secados até 11,2 , 12,8 e 14,8\% b.u., armazenados a 20, 30 e $40^{\circ} \mathrm{C}$. A cada 45 dias até 180 dias de armazenamento, foram determinados 0 teor de ácidos graxos livres, o índice de peróxido, o índice de iodo e o índice fotométrico de cor do óleo bruto. Em geral, o percentual de ácidos graxos livres aumentou, exceto no óleo extraído dos grãos armazenados com 11,2\% a $20^{\circ} \mathrm{C}$. 0 índice de peróxido e o índice fotométrico de cor do óleo aumentaram significativamente em todas as condições de armazenagem; entretanto, este comportamento foi mais acentuado no óleo extraído dos grãos armazenados com maior teor de água e temperatura mais elevada. Pode-se concluir, com base nos resultados, que é possível armazenar grãos de soja com teor de água de até $15,0 \%$ (b.u.) a $20{ }^{\circ} \mathrm{C}$, sem afetar a qualidade do óleo bruto, por 180 dias, e obter, ainda, óleo bruto de soja com qualidade, dentro dos padrões exigidos para comercialização no Brasil, de soja armazenada com até $13,0 \%$ de teor de água a $30^{\circ} \mathrm{C}$, durante 180 dias.
\end{abstract}

Palavraschave: qualidade de soja, rancidez hidrolítica, rancidez oxidativa

3 Departamento de Tecnologia de Alimentos, UFV. Fone: (31) 3899-1856. E-mail: mtulio@ufv.br 


\section{INTRODUCTION}

Among the 17 commodity fats and oils, soybean (Glycine $\max (\mathrm{L}$.) Merrill) is the first most produced vegetable oil in the world (Gunstone, 2001; Farhoosh et al., 2009). Soybean contains about $20 \%$ oil, which is susceptible to a deteriorative process due to inadequate grain storage, leading to high losses in the food industry. Depending upon the duration and conditions of storage, physical, chemical and biochemical alterations can occur in the soybeans (Narayan et al., 1988; Hou \& Chang, 2002; Hou \& Chang, 2005; Kong et al., 2008; Shelar et al., 2008), and such qualitative changes contribute to reduced oil, meal quality and tofu (Liu, 1997; Hou \& Chang, 1998; Chang, 2005).

The major factors affecting the storability of soybeans include ambient relative humidity, seed initial moisture content, temperature, and time duration of storage (Kong \& Chang, 2009). Storing soybeans with inadequate moisture content (m.c.) leads to deterioration of crude, refined, bleached and deodorized oil. The free fatty acid (FFA) content, iodine and peroxide index, are the parameters generally used to evaluate grain damage and oil quality (Frankel et al., 1987; Lovaas, 1992; Regitano D’Arce et al., 1994). In addition to the losses that occur during oil refinement, the crude oil from severely damaged grains is more difficult to degum and the refined oil is darker than that obtained from healthy grains (List et al., 1977).

The oil degradation can be caused by oxidation, hydrolysis, polymerization, pyrolises and absorption of external flavors and odors. The oxidative reactions can be influenced by several factors such as light, heat, ionization, traces of metals, and metaloprotein, oxygen reaction with unsaturated lipids, and by chemical, and enzymatic mechanisms such as autoxidation, photo-oxidation and lipoxygenases (Araújo, 2004).

During grain storage, especially at high moisture and temperature, the lipids are hydrolyzed by lipase into FFA and glycerol, and the process is accelerated by fungal growth (Heaton et al., 1978; Rupollo et al., 2004; Guehi et al., 2007). Storing soybeans with $13 \%$ or higher m.c. permits fungal colonization resulting in FFA increase (Christensen, 1967).

Although there are several studies about changes in soybean oil quality due to storage conditions, most data come from temperate ecosystems where temperatures during soybean storage remain low, and therefore are not applicable under tropical or sub-tropical ecosystems, like Brazil, where temperatures during the storage season remain above $20^{\circ} \mathrm{C}$, and in some regions can reach over $30^{\circ} \mathrm{C}$. No data are available regarding the fate and behavior of oil in soybeans stored under such conditions. Therefore adequate grain moisture, for at least 6-month storage under high temperature ranges needs, to be determined to reduce the risk of qualitative loss during storage.

Prediction of qualitative grain deterioration is very important, because sometimes it is necessary to store for one year to another, and safe storage period is dependent upon the quantitative relation between deterioration rate, quality and storage conditions (Tang et al., 1999). Thus, the follow- ing study was done to determine the temporal changes in the quality of oil extracted from soybeans stored under different combinations of grain moisture and temperature, to help design strategies for handling and storing soybeans under tropical conditions.

\section{MATERIAL AND METHODS}

The study was done in the Pre-Processing and Storage of Agricultural Products Laboratory, Department of Agricultural Engineering, Federal University of Viçosa.

Soybean grains were obtained from Almeida Campos district, Nova Ponte, MG. The grains were harvested with $\mathrm{m}$. c. of about $18 \%$ (w.b.), and dried to $11.2,12.8$ or $14.8 \%$ m.c. in a fixed layer drier with forced natural air, and stored in $3 \mathrm{~L}$ plastic containers in chambers held at 20,30 or $40^{\circ} \mathrm{C}$.

To assure initial grain m.c. during storage, the equilibrium relative humidity (ERH), was calculated using ChungPfost model (Navarro \& Noyes, 2001) for each temperaturem.c. combination (Table 1), and relative humidity (RH) in each chamber was controlled accordingly. The data were monitored and recorded by the use of a computational system 1-wire ${ }^{T M}$ (Martins et al., 2004).

Table 1. Equilibrium relative humidity (ERH) for each combination of moisture content and temperature

\begin{tabular}{cccc}
\hline \multirow{2}{*}{ Temp. ( $\left.{ }^{\circ} \mathrm{C}\right)$} & \multicolumn{3}{c}{ Moisture content (\%) } \\
\cline { 2 - 4 } 20 & $\mathbf{1 1 . 2}$ & $\mathbf{1 2 . 8}$ & $\mathbf{1 4 . 8}$ \\
30 & 61.0 & 72.0 & 80.0 \\
40 & 67.0 & 76.0 & 83.0 \\
\hline
\end{tabular}

During storage, the grains were sampled at 45-day intervals for 180 days, to analyze FFA, peroxide, iodine and photometric index according to the protocols Ca 5a-40, Cd 8-53, Cd 1b-87 and Cd 8-53 respectively of AOCS (2009). The crude oil of the grains was obtained according to protocol Ac 3-44.

The study was conducted in a completely randomized design in split plot mode with three replications. The main treatments were allotted to the plots and the storage period to the sub-plots, thus the treatment structures corresponded to a $3 \times 3 \times 5$ factorial. Analysis of variance considering repeated measures was performed initially to determine the most suited structure of residual covariance. Regression analysis was used for FFA, peroxide and photometric index.

\section{RESULTS AND DISCUSSION}

\section{Free fatty acid content}

There was a significant difference $(\mathrm{p}<0.05)$ in the FFA content of oil extracted from grains stored at different $\mathrm{m}$. c. and temperatures, with a significant interaction between m.c., temperature and storage period.

The regression curves of the FFA (expressed as \% oleic 
acid) content in oil from grains stored under different conditions are shown in Figure 1. The FFA content of oil from grain with m.c. up to $14.8 \%$ stored at $20^{\circ} \mathrm{C}$ did not change significantly during the entire storage period. However, it increased significantly, independently of m.c., if storage was done at 30 or $40^{\circ} \mathrm{C}$ (Figure $1 \mathrm{~B}$ and $1 \mathrm{C}$ ), but the increase was more accentuated in grains with $14.8 \%$ m.c. The adjusted regression equation with their respective coefficients of de-
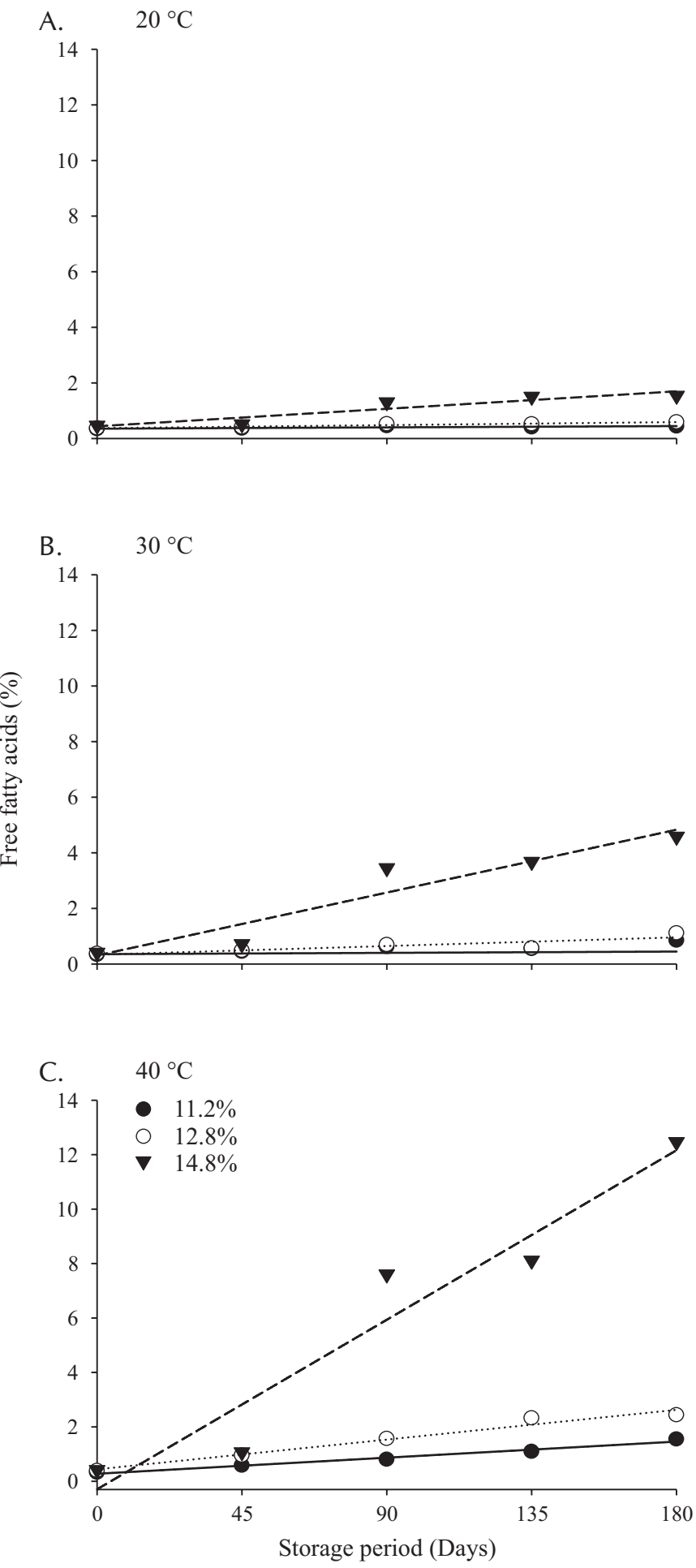

Figure 1. Temporal changes in free fatty acid (expressed as \% oleic acid) content of crude oil extracted from soybeans of different moisture contents, stored at different temperatures termination, relating \% FFA content with the grain moisture and storage time, are given in Table 2.

Table2. Adjusted regression equations for free fatty acid content of crude oil extracted from soybeans of different moisture contents (m.c.) stored for six months at different temperatures $(T)$

\begin{tabular}{cclccc}
\hline $\mathbf{T}\left({ }^{\circ} \mathbf{C}\right)$ & m.c. (\%) & Adjusted regression & $\mathbf{R}^{2}$ & $\mathbf{F}$ & Prob. \\
\multirow{4}{*}{20} & 11.2 & $\hat{y}=0.41$ & & 7.11 & 0.0194 \\
& 12.8 & $\hat{y}=0.370+0.0012 X$ & 0.85 & 76.02 & $<0.0001$ \\
& 14.8 & $\hat{y}=0.438+0.0069 X$ & 0.80 & 51.17 & $<0.0001$ \\
\hline \multirow{3}{*}{30} & 11.2 & $\hat{y}=0.352+0.025 X$ & 0.82 & 51.12 & $<0.0001$ \\
& 12.8 & $\hat{y}=0.332+0.035 X$ & 0.72 & 33.69 & $<0.0001$ \\
& 14.8 & $\hat{y}=0.307+0.0251 X$ & 0.86 & 77.93 & $<0.0001$ \\
\hline \multirow{3}{*}{40} & 11.2 & $\hat{y}=0.277+0.0066 X$ & 0.96 & 314.00 & $<0.0001$ \\
& 12.8 & $\hat{y}=0.440+0.0121 X$ & 0.87 & 83.43 & $<0.0001$ \\
& 14.8 & $\hat{y}=-0.294+0.0692 X$ & 0.84 & 72.04 & $<0.0001$ \\
\hline
\end{tabular}

Since the Brazilian marketing standard for FFA content of crude soybean oil is 2\% (ANVISA, 1999), the oil from grains with $14.8 \%$ m.c. stored at 30 or $40{ }^{\circ} \mathrm{C}$ and those with $12.8 \%$ m.c. stored at $40^{\circ} \mathrm{C}$ can have FFA content above this limit after 90 and 135-day storage, respectively.

The FFA content of oil increases due to lipid hydrolysis by lipases, peroxidases and phospholipases enzymes present in grain tissues or produced by the associated microorganisms (Zadernowski et al., 1999). There are several reports relating FFA increase under storage conditions. Yanagi et al. (1985) reported the influence of storage duration on FFA content of oil from soybeans with 13.7 or $9.3 \%$ m.c. stored at $30{ }^{\circ} \mathrm{C}$ and $80 \% \mathrm{RH}$. The changes in FFA content of oil from soybeans stored at different m.c. were also reported by Frankel et al. (1987). The grains stored with 13\% m.c showed less FFA increase compared to those stored with 16 or $20 \%$ m.c. While the FFA content of oil from soybeans stored at $13 \%$ m.c. increased from 0.2 to $1.25 \%$ after 49 day storage, that of grains with 16 or $20 \%$ m.c. increased from 0.5 to $2.0 \%$ after 27 days, and from 0.6 to $2.3 \%$ after 28 days, respectively. Narayan et al. (1988) also reported temporal FFA increase in soybeans stored under ambient conditions, from $0.69 \%$ to $9.85 \%$, after 58 -month storage. According to Dhingra et al. (1998) the FFA content of oil extracted from soybean increased significantly due to the interaction between m.c. and storage period.

\section{Peroxide index}

The oil peroxide index differed significantly $(\mathrm{p}<0.05)$ among samples due to the interaction between m.c., temperature and storage period. The regression curves of temporal changes in peroxide index are shown in Figure 2, with the adjusted regression equations and respective coefficients of determination in Table 3, which correlate the peroxide index to the m.c. at each temperature.

Oil peroxide index increased independent of storage temperature, but the increase was less accentuated if the grains were stored with 11.2 or $12.8 \%$ m.c. at 20 or $30^{\circ} \mathrm{C}$ (Figure 2A and B), but increased sharply if stored at $40^{\circ} \mathrm{C}$ independently of the grain m.c. (Figure 2C). These findings 

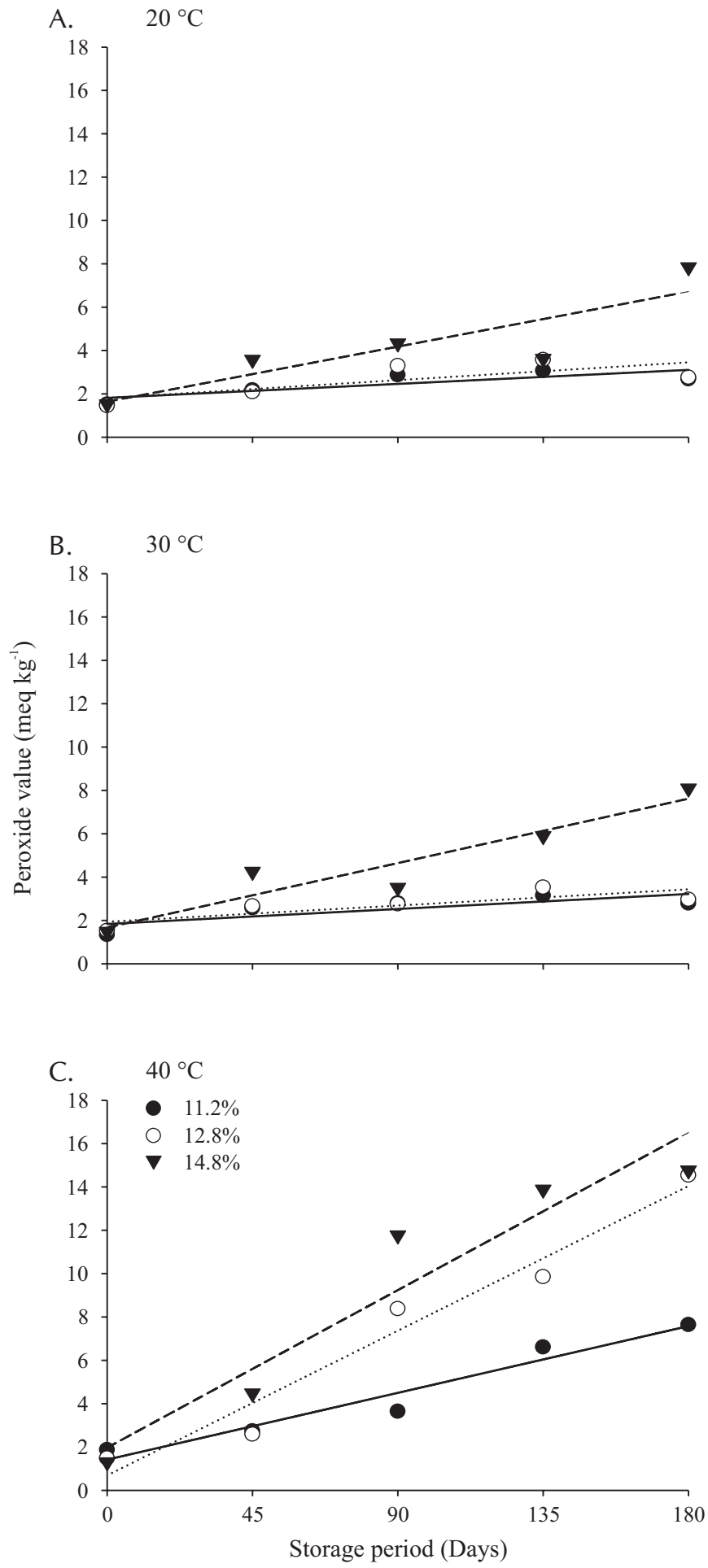

Figure 2. Temporal changes in peroxide value of crude oil extracted from soybeans of different moisture contents, stored at different temperatures

are similar to those of Narayan et al. (1988), where oil peroxide index increased from 18 to 98 meq $\mathrm{kg}^{-1}$ after 58-month storage under ambient conditions.

Lipid oxidation is the major cause of oil and fat deterioration due to formation of hydroperoxides resulting from the reaction between oxygen and the unsaturated fatty acids. Although these hydroxides have no flavor or taste, they
Table 3. Adjusted regression equations for peroxide value in crude oils extracted from soybeans as a function of storage period for each combination of temperature (T) and moisture content (m.c.)

\begin{tabular}{cccccl}
\hline $\mathbf{T}\left({ }^{\circ} \mathbf{C}\right)$ & m.c. $(\%)$ & Adjusted regression & $\mathbf{R}^{2}$ & $\mathbf{F}$ & Prob. \\
& 11.2 & $\hat{y}=1.812+0.0072 \mathrm{X}$ & 0.42 & 9.51 & 0.0087 \\
20 & 12.8 & $\hat{y}=1.810+0.0091 \mathrm{X}$ & 0.45 & 10.61 & 0.0062 \\
& 14.8 & $\hat{y}=1.640+0.0282 \mathrm{X}$ & 0.74 & 37.88 & $<0.0001$ \\
\hline \multirow{3}{*}{30} & 11.2 & $\hat{y}=1.835+0.0077 \mathrm{X}$ & 0.56 & 16.37 & 0.0014 \\
& 12.8 & $\hat{y}=1.939+0.0083 \mathrm{X}$ & 0.47 & 11.46 & 0.0049 \\
& 14.8 & $\hat{y}=1.672+0.0330 \mathrm{X}$ & 0.75 & 40.08 & $<0.0001$ \\
\hline \multirow{3}{*}{40} & 11.2 & $\hat{y}=1.417+0.0342 \mathrm{X}$ & 0.78 & 45.77 & $<0.0001$ \\
& 12.8 & $\hat{y}=0.686+0.0742 \mathrm{X}$ & 0.94 & 193.98 & $<0.0001$ \\
& 14.8 & $\hat{y}=1.968+0.0808 \mathrm{X}$ & 0.90 & 115.06 & $<0.0001$ \\
\hline
\end{tabular}

rapidly decompose to aldehydes, ketones, alcohols, hydrocarbons, esters, furans and lactones, which impart disagreeable taste and odor (Lovaas, 1992; O’Brien, 2004; Farhoosh et al., 2009).

The peroxide index is the most common parameter used to characterize oils and fats (O’Brien, 2004); a product with peroxide value between 1 and 5 meq kg-1 is classified at low oxidation state; that between 5 and 10 meq kg-1 at moder-

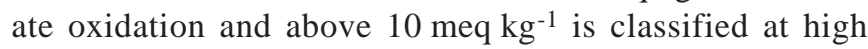
oxidation state. The peroxide index obtained in the present study showed that the grains stored with 11.2 or $12.8 \%$ m.c. at 20 or $30^{\circ} \mathrm{C}$ yielded oil that can be characterized as having a low oxidation state. On the other hand, the oil from grains with 12.8 or $14.8 \%$ m.c. stored at $40{ }^{\circ} \mathrm{C}$ had a high oxidation state after six or three month storage, respectively. It is worth emphasizing that the maximum limit for peroxide value established by the Brazilian legislation for commercialization of soybean crude oil is 10 meq $\mathrm{kg}^{-1}$ (ANVISA, 1999).

\section{Iodine index}

The oil iodine index did not differ significantly among samples $(p>0.05)$ due to interaction between grain m.c., temperature and storage period, although there was a significant variation along the storage period. Dhingra et al. (1998), while studying the oil quality of soybeans stored at different m.c. at $25^{\circ} \mathrm{C}$, and colonized by Aspergillus ruber, also did not find significant variation in the iodine index.

\section{Photometric color index}

There was significant variation $(p<0.05)$ in the photometric color index due to interaction between m.c., temperature and storage period. The temporal increase of photometric color index of oil at each storage temperature is shown in Figure 3, with the regression equations and their respective coefficients of determination in Table 4.

Photometric color index increased along the storage period, independently of the grain m.c. and storage temperature, but the increase rate was positively related to m.c. and storage temperature. These results were confirmed by grain darkening, especially at high m.c. and temperatures. This rapid increase of photometric color index of the oil 

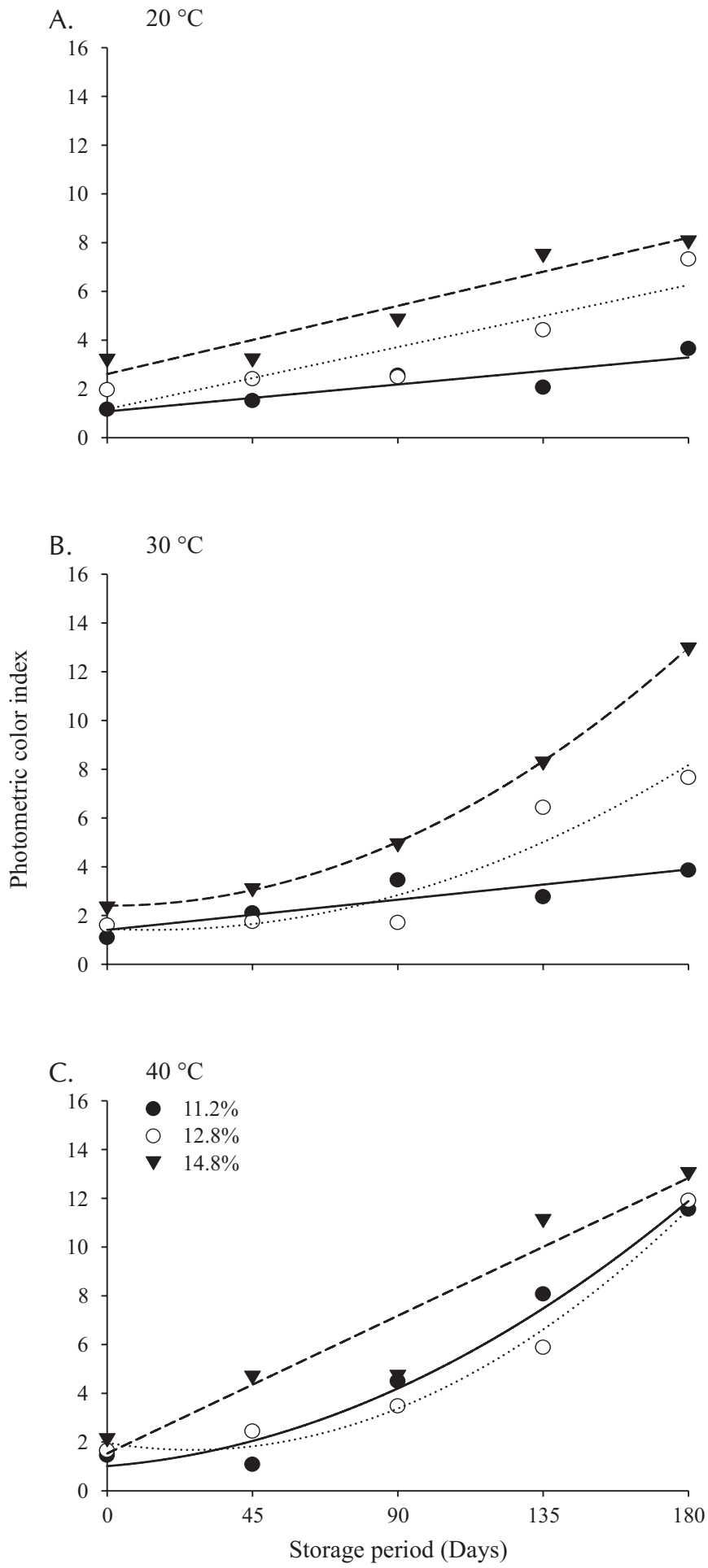

Figure 3. Temporal changes in photometric color index of crude oil extracted from soybeans of different moisture contents, stored at different temperatures

from grains with high m.c. could be due to colonization by storage fungi as reported by (Wilson et al., 1995). It is worth emphasizing that, at the end of the 180-day storage, $87 \%$ of the grains were found to be colonized by Aspergillus glaucus, resulting in a high percentage of sour grains.
Table 4. Adjusted regression equations for photometric color index in crude oils extracted from soybeans as a function of storage period for each combination of temperature ( $T$ ) and moisture content (m.c.) and respective determination coefficients

\begin{tabular}{ccccccc}
\hline $\mathbf{T}\left({ }^{\circ} \mathbf{C}\right)$ & m.c. (\%) & Adjusted regression & $\mathbf{R}^{2}$ & $\mathbf{F}$ & Prob. \\
& 11.2 & $\hat{y}=1.07+0.0123 \mathrm{X}$ & 0.59 & 18.7 & $<0.001$ \\
20 & 12.8 & $\hat{y}=1.17+0.0283 \mathrm{X}$ & 0.74 & 36.3 & $<0.001$ \\
& 14.8 & $\hat{y}=2.60+0.0311 \mathrm{X}$ & 0.51 & 13.7 & $<0.01$ \\
\hline \multirow{4}{*}{30} & 11.2 & $\hat{y}=1.41+0.0138 \mathrm{X}$ & 0.46 & 10.9 & $<0.01$ \\
& 12.8 & $\hat{y}=1.46-0.0067 \mathrm{X}+0.0002 \mathrm{X}^{2}$ & 0.74 & 17.8 & $<0.001$ \\
& 14.8 & $\hat{y}=2.40-0.0007 \mathrm{X}+0.0003 \mathrm{X}^{2}$ & 0.85 & 32.9 & $<0.001$ \\
\hline \multirow{3}{*}{40} & 11.2 & $\hat{y}=1.01+0.010 \mathrm{X}+0.0003 \mathrm{X}^{2}$ & 0.90 & 51.8 & $<0.001$ \\
& 12.8 & $\hat{y}=1.97-0.022 \mathrm{X}+0.0004 \mathrm{X}^{2}$ & 0.95 & 109.8 & $<0.001$ \\
& 14.8 & $\hat{y}=1.52+0.0628 \mathrm{X}$ & 0.90 & 112.7 & $<0.001$ \\
\hline
\end{tabular}

\section{CONCLUSION}

1. The combination of high grain moisture and temperature during soybean storage accelerates the oil deterioration process.

2. Storage of soybean grains with moisture content up to $15.0 \%$ (w.b.), at $20^{\circ} \mathrm{C}$, does not affect the quality of the crude oil.

3. Crude oil obtained from soybean grains stored with moisture content up to $13.0 \%$ (w.b.), at $30{ }^{\circ} \mathrm{C}$ maintains satisfactory quality up to 180 days.

4. It is not possible to obtain crude oil, within the quality standards demanded for commercialization, from soybean grains stored with moisture content above $11.0 \%$ (w.b.) at the temperature of $40^{\circ} \mathrm{C}$.

\section{LITERATURE CITED}

ANVISA - Agência Nacional de Vigilância Sanitária. Regulamento técnico para fixação de identidade e qualidade de óleos e gorduras vegetais. Resolução n.482, de 23.09.1999.

AOCS - American Oil Chemists' Society. Official methods and recommended practices. 6.ed. Champaign: AOCS, 2009. 1200p.

Araújo, J. M. A. Química de alimentos: Teoria e prática. Viçosa: UFV, 2004. 416p.

Chang, S. K. C. Chemistry and technology of tofu making. In: Hiu, Y. H. (ed.). Handbook of food science technology and engineering. Boca Raton: CRC Press, 2005. cap.171, p.1-24.

Christensen, C. M. Increase in invasion by storage fungi and fat acidity values of commercial lots of soybean stored at moisture contents of 13.0-14.0\%. Phytopatology, v.57, p.622-624, 1967.

Dhingra, O. D.; Jham, G.; Napoleão, I. T. Ergosterol accumulation and oil quality changes in stored soybean invaded by Aspergillus ruber (A. glaucus group). Mycopathologia, v.143, p.85-91, 1998.

Farhoosh, R.; Einafshar' S.; Sharayei, P. The effect of commercial refining steps on the rancidity measures of soybean and canola oils. Food Chemistry, v.115, p.933-938, 2009. 
Frankel, E. N.; Nash, A. M.; Snyder, J. M. A methodology study to evaluate quality of soybeans stored at different moisture levels. Journal of the American Oil Chemists' Society, v.64, n.7, p.987-992, 1987.

Guehi, T. S.; Dingkuhn, M.; Cros, E.; Fourny, G.; Ratomahenina, R.; Moulin, G.; Vidal, A. C. Identification and lipase-producing abilities of moulds isolated from ivorian raw cocoa beans. Research Journal of Agriculture and Biological Sciences, v.3, n.6, p.838-843, 2007.

Gunstone, F. Production and consumption of rapeseed oil on a global scale. European Journal of Lipid Science and Technology, v.103, p.447-449, 2001.

Heaton, T. C.; Knowles, P. F.; Mikkelsen, D. S.; Ruckman J. E. Production of free fatty acids in safflower seeds by fungi. Journal of the American Oil Chemists' Society, v.55, n.5, p.465468, 1978.

Hou, H. J.; Chang, K. C. Yield and quality of soft tofu as affected by soybean physical damage and storage. Journal of Agricultural and Food Chemistry, v.46, p.4798-4805, 1998.

Hou, H. J.; Chang, K. C. Interconversions of isoflavones in soybeans as affected by storage. Journal of Food Science, v.67, n.6, p.2083-2089, 2002.

Hou, H. J.; Chang, K. C. Storage conditions affect soybean color, chemical composition and tofu qualities. Journal of Food Processing and Preservation, v.28, n.6, p.473-488, 2005.

Kong, F.; Chang, S. K. C. Statistical and kinetic studies of the changes in soybean quality during storage as related to soymilk and tofu making. Journal of Food Science, v.74, n.2, p.S81-S89, 2009.

Kong, F.; Chang, S. K. C.; Liu, Z.; Wilson, L. A. Changes of soybean quality during storage as related to soymilk and tofu making. Journal of Food Science, v.73, n.3, p.S134-S144, 2008.

List, G. R.; Evans, C. D.; Warner, K.; Beal, R. E.; Kwolek, W. F.; Black, L. T.; Moulton, K. J. Quality of oil from damaged soybeans. Journal of the American Oil Chemists' Society, v.54, n.1, p.8-14, 1977.

Liu, K. Soybeans: Chemistry, technology and utilization. New York: Chapman \& Hall, 1997. 532p.
Lovaas, E. A. Sensitive spectrophotometric method for lipid hydroperoxide determination. Journal of the American Oil Chemists’ Society, v.69, p.777-783, 1992.

Martins, J. H.; Monteiro, P. M. B.; Mota, A. M. N.; Fonseca, J. A. G. The 1-wire ${ }^{T M}$ system - an application for agricultural processes. In: Portuguese Conference on Automatic Control. 6, 2004, Faro. Proceedings... Faro: Controlo, 2004. 5p.

Narayan, R.; Chauhan, G. S.; Verma, N. S. Changes in the quality of soybean during storage. Part 1 - Effect of storage on some physico-chemical properties of soybean. Food Chemistry, v.27, p.12-23, 1988.

Navarro, S.; Noyes, S. T. The mechanics and physics of modern grain aeration management. Boca Raton: CRC Press, 2001. 672p.

O’Brien, R. D. Fats and oils formulating and processing for applications. Boca Raton: CRC, 2004. 616p.

Regitano D’Arce, M. A. B.; Rauenmiguel, A. M. O.; Casagrande, J. R. R.; Marcos, E. A.; Plonis, G. Time of harvesting and storage of soybeans - influence on oil quality. Grasas y aceites, v.45, n.4, p.237-240, 1994.

Rupollo, G.; Gutkoski, L. C.; Marini, L. J.; Elias, M. C. Sistemas de armazenamentos hermético e convencional na conservabilidade de grãos de aveia. Ciência Rural, v.34, n.6, p.1715-1722, 2004.

Shelar, V. R.; Shaikh, R. S.; Nikam, A. S. Soybean seed quality during storage: A review. Agricultural Reviews, v.29, n.2, p.125-131, 2008.

Tang, S.; Tekrony, D. M.; Egli, D. B.; Cornelius, P. L. Survival characteristics of corn seed during storage: II. Rate of seed deterioration. Crop Science, v.39, p.1400-1406, 1999.

Wilson, R. F.; Novitzky, W. P.; Fenner, G. P. Effect of fungal damage on seed composition and quality of soybeans. Journal of the American Oil Chemists' Society, v.72, n.12, p.1425-1429, 1995.

Yanagi, S. O.; Galeazzi, M. A. M.; Saio, K. Properties of soybean in model storage studies. Agricultural and Biological Chemistry, v.49, p.525-528, 1985.

Zadernowski R.; Nowak-Polakowska H.; Rashed, A. A. The influence of heat treatament on the activity of lipo and hydrophilic components of oat grain. Journal of Food Processing and Preservation, v.33, p.177-191, 1999. 